\title{
Degreening of Red Spanish pineapple after field heat removal ${ }^{1,2}$
}

\author{
Rubén Guadalupe-Luna, ${ }^{,}$Isabel Beauchamp de Caloni' and Carmen \\ Chao de Baez
}

\begin{abstract}
Red Spanish pineapple mature green fruits, were selected from the Land Authority's pineapple program and taken to the Food Technology Laboratory for a study of degreening. Field heat was removed for $24 \mathrm{~h}$ at three different temperatures: $45^{\circ} \mathrm{F}\left(7^{\circ} \mathrm{C}\right)$ in a controlled temperature and humidity chamber, $68^{\circ} \mathrm{F}\left(20^{\circ} \mathrm{C}\right)$ in a ripening room, and $78-82^{\circ} \mathrm{F}(26$ $28^{\circ} \mathrm{C}$ ) in an open room. After $\mathbf{2 4} \mathrm{h}$, all the fruit were placed in the ripening room where either 1 or 2 doses of ethylene were applied. Fruits were then maintained in this ripening room for another $24 \mathrm{~h}$ after each application. After this procedure, the fruits were stored at $45^{\circ} \mathrm{F}$ and $75-85 \%$ humidity for 5 days, observed and analyzed. One additional group of 30-40 fruits was used as control and held without ethylene treatment at $45^{\circ} \mathrm{F}\left(7^{\circ} \mathrm{C}\right)$ in a controlled temperature and humidity chamber. Ethylene treatments did not affect the overall quality of the fruits, but increased the intensity of shell yellow color irrespective of the number of ethylene shots and the precooling temperatures. Fifty-nine percent of the control samples that were held without any ethylene application remained green. The storage of pineapple for 3 additional days at $68^{\circ} \mathrm{F}$ following the $45^{\circ} \mathrm{F}$ storage, made it possible for fruits to reach the yellow color (Full index) no matter the number of ethylene shots applied. This study indicates that mature green Red Spanish pineapples can be treated with ethylene gas before exportation to assure removal of the shell green pigment, thus making them more attractive to potential consumers.
\end{abstract}

\section{RESUMEN}

Remoción del color verde en la piña Española Roja

Para estudiar la posibilidad de eliminarle el color verde a la cástara de la piña ${ }^{\circ}$ Española Roja, se trajeron muestras del Programa de Piña de la Autoridad de Tierras de Puerto Rico al Laboratorio de Tecnología de Alimentos. Se les eliminó el calor de campo durante $\mathbf{2 4} \mathrm{h}$. mediante los siguientes tratamientos de temperatura: $45^{\circ} \mathrm{F}$. $\left(7^{\circ} \mathrm{C}\right.$.) en cámara con temperafura y humedad controlada, $68^{\circ} \mathrm{F} .\left(20^{\circ} \mathrm{C}\right.$.) en cámara de maduración y $78-82^{\circ}$ F. $\left(26-28^{\circ} \mathrm{C}\right.$.) en cuarto abierto. Las muestras se dividieron en dos grupos. De éstos, un grupo recibió un tratamiento de etileno por $\mathbf{2 4} \mathrm{h}$. $y$ el otro grupo dos tratamientos de etileno por 48 h. Luego de este pro-

'Manuscript submitted to Editorial Board 8 June 1990.

2This study was conducted under CBAG-28 Postharvest Technology of Tropical Fruits and Vegetables Produced in Puerto Rico.

${ }^{3}$ Horticulturist, Department of Horticulture.

${ }^{4}$ Food Technologist, Laboratory of Food Technology.

${ }^{5}$ Associate Statistician, Statistics Section.

${ }^{6}$ Ananás; Ananas comosus (L.) Merrill. 
cedimiento, todas las frutas se almacenaron por 5 días a temperatura de $45^{\circ} \mathrm{F}$. A un grupo adicional que sirvió de control no se le aplicó tratamiento de etileno y permaneció a $45^{\circ} \mathrm{F}$. Se encontró que del control que no se trató con etileno, el $59 \%$ de las frutas permanecieron verdes. Las frutas a las que se les quitó el calor de campo por $24 \mathrm{~h}$. a temperatura de $45^{\circ} \mathrm{F}$., $68^{\circ} \mathrm{F}$. y ambiente, cambiaron el color prescindiendo de recibir 1 ó 2 tratamientos de etileno. Almacenar las piñas por 3 días adicionales en condiciones de supermercado $\left(68^{\circ} \mathrm{F}\right.$.) permitió que un gran número de frutas alcanzaran el índice de completamente amarilla sin tener en cuenta el número de aplicaciones de etileno. En el caso del testigo que no recibió etileno, ninguna de las frutas amarillecieron, quedando la gran mayoría (80\%) en índice 3.

A la piña al igual que a las cítricas, aunque son frutas no climatéricas, se les puede quitar el verde en un mayor o menor grado dependiendo del número de aplicaciones de etileno y de la temperatura de almacén durante las primeras $\mathbf{2 4} \mathbf{h}$. Esto permitiría llevar al supermercado frutas más atractivas y en menos días de cosechadas sin tener que esperar por la maduración natural.

\section{INTRODUCTION}

The purpose of this work was to study degreening of mature gxeen Red Spanish pineapple with ethylene gas in an attempt to change surface area color to a more attractive yellow without having to wait for the natural yellowing process.

Pineaple (Ananas comosus L.) is one of the most important economic fruit crops in Puerto Rico. In 1988, the market value of the pineapple production was $\$ 19.5$ million (1). The principal commercial pineapple variety grown is the Red Spanish, although other less important varieties are also grown, especially for the fresh market. The total yearly production of all varieties fluctuated somewhat in 1987-88, with an average slightly over 75 metric tons (1). During this period, $95 \%$ of the total production was processed in various forms for both local and export trade, whereas the remainder was sold as fresh fruit either in local or United States markets.

The stage of maturity at which the fruits should be picked depends largely on its ultimate destination or use $(5,6)$. Fruit with slightly yellow to one-half yellow surface area have better shelf life than those with more surface color, whereas fruits with no yellow are not attractive to the consumer (8). For local use, pineapples are usually picked when $25 \%$ or more yellow surface is observed. If the fruits are to be sold as fresh, especially if the growing area is far from the market, they are usually harvested when all the eyes are still green and have no trace of yellow color (mature green) $(3,6)$.

At this green ripe stage, since pineapples are a nonclimateric fruit (5, 8), there is no starch reserve that allows major postharvest quality improvements and the fruit does not have an attractive appearance. Since most consumers associate a green extemal color with lack of maturity, removal of the green pigment before marketing is desireable (7). Any 
surface color improvement achieved will upgrade the fruit's appearance and thus consumers' acceptability. After the mature green stage, pineapple shell loses chlorophyll from the base up in a process similar to that observed in degreening citrus fruits $(2,8)$.

\section{MATERIALS AND METHODS}

Mature green Red Spanish pineapples were selected from the Land Authority Pineapple Program and taken to the Food Technology Laboratory where they were divided in three groups (60 - 80 fruits each) and submitted to several temperature and ethylene treatments. The internal temperature was recorded and the field heat was removed for $24 \mathrm{~h}$ at $45^{\circ}$ $\mathrm{F}$ (in a controlled temperature and humidity chamber at $85 \%$ relative humidity), $68^{\circ} \mathrm{F}$ (in a ripening room), and $78-82^{\circ} \mathrm{F}$ (in an open room). After this 24-h period, each of the three groups were subsequently divided into two subgroups and all samples were placed in the ripening room $\left(68^{\circ} \mathrm{F}\right.$.). Each of these subgroups received one shot of ethylene gas (one cubic foot per 1,000 cubic feet of ripening room) administered from a large cylinder, and all fruits were maintained inside the ripening room for $24 \mathrm{~h}$. One subgroup of each group was retrieved from the ripening room after this 24-h holding period. The other subgroup of each group, once the ripening room was ventilated for 20 minutes, received a second shot of ethylene and remained in the ripening room for an additional 24 h. One additional group of 30 - 40 fruits was used as a control and held without ethylene treatment at $45^{\circ} \mathrm{F}\left(7^{\circ} \mathrm{C}\right)$ in a controlled temperature and humidity chamber (at $85 \%$ relative humidity).

After the ethylene treatments, pineapples were stored at $45^{\circ} \mathrm{F}\left(7^{\circ} \mathrm{C}\right)$ and $75-85 \%$ relative humidity for 5 days (the time it takes for pineapples to reach the US) and for 3 additional days $68^{\circ} \mathrm{F}\left(20^{\circ} \mathrm{C}\right)$ after removal from the environmental chamber (to simulate retail market conditions).

Both before and after treatments all fruits were evaluated for appeareance, flavor, texture (mouth feel), overall acceptability, Brix, $\mathrm{pH}$, acidity, total solids and Brix/acid ratio. Fruit weight loss during storage was determined. Shell color development was subjectively determined and rated on a scale from 1 to 5 , on the basis of percentage of non-green surface area: $1=0 \%, 2=1-25 \%, 3=26-50 \%, 4=51-75 \%, 5=100 \%$ yellow color (4). The fruits were sensory evaluated, with a 6-point hedonic scale ranging from $6=$ like very much to $1=$ do not like.

\section{RESULTS AND DISCUSSION}

Tables $1,2,3$ and 4 summarize the data obtained in this study. Ethylene treatments did not affect the overall quality of the fruits, but increased the intensity of yellow of the the peel.

Table 1 shows results obtained when mature green fruits were treated with ethylene after precooling at $45^{\circ} \mathrm{F}, 68^{\circ} \mathrm{F}$ and room temper- 
TABLE 1.-Degreening of pineapple after field heat removal at three different temperatures

\begin{tabular}{|c|c|c|c|c|c|c|c|}
\hline \multirow[b]{2}{*}{ Ethylene } & \multirow[b]{2}{*}{ Temp ( $\left.{ }^{\circ} \mathrm{F}\right)$} & \multirow[b]{2}{*}{ Days } & \multicolumn{5}{|c|}{ Color development index } \\
\hline & & & 1 & 2 & 3 & 4 & 5 \\
\hline \multirow[t]{2}{*}{0} & 45 & 5 & $59^{2}$ & 37 & 4 & 0 & 0 \\
\hline & & $8^{3}$ & 0 & 0 & 80 & 20 & 0 \\
\hline 1 & 45 & 5 & & 73 & 27 & 0 & 0 \\
\hline \multirow{5}{*}{ shot } & & 8 & & 8 & 31 & 41 & 20 \\
\hline & 68 & 5 & & 23 & 43 & 34 & 0 \\
\hline & & 8 & & 0 & 4 & 66 & 30 \\
\hline & $78-82$ & 5 & & 0 & 32 & 50 & 18 \\
\hline & & 8 & & 0 & 7 & 66 & 30 \\
\hline 2 & 45 & 5 & & 25 & 43 & 32 & 0 \\
\hline \multirow[t]{5}{*}{ shots } & & 8 & & 0 & 32 & 55 & 13 \\
\hline & 68 & 5 & & 0 & 10 & 23 & 67 \\
\hline & & 8 & & 0 & 3 & 25 & 72 \\
\hline & $78-82$ & 5 & & 0 & 7 & 25 & 68 \\
\hline & & 8 & & 0 & 0 & 25 & 75 \\
\hline
\end{tabular}

$1=0 \%, 2=1-25 \%, 3=26-50 \%, 4=51-75 \%, 5=76-100 \%$ surface yellow color.

2Percent of fruits.

${ }^{\text {oTh }} 3$ additional days of storage were at $68^{\circ} \mathrm{F}$.

ature $\left(78-82^{\circ} \mathrm{F}\right)$ for $24 \mathrm{~h}$. These treatments could make pineapples more attractive by changing their color to a yellow index of 2 or higher, depending on the number of ethylene shots and precooling temperature.

The fruits in which the field heat was removed at $45^{\circ} \mathrm{F}$ changed their green peel color irrespective of whether they received 1 or 2 ethylene applications. Seventy-three percent of the fruits that received one treatment changed color to a 2 -index, whereas the remaining $27 \%$ changed color to 3-index within 5 days of storage. Among those receiving two ethylene applications and stored at $45^{\circ} \mathrm{F}, 68 \%$ reached a 2 and 3 yellow index after 5 days.

All the fruits from which the field heat was removed at $68^{\circ} \mathrm{F}$ changed in color irrespective of whether they received one or two shots of ethylene. Seventy-seven percent of the fruits that received one ethylene application reached the 3 and 4 yellow color index, whereas $67 \%$ of those that received two applications reached a full yellow color index within 5 days of storage.

The fruits that were exposed to room temperature $\left(78-82^{\circ} \mathrm{F}\right)$ for 24 $h$ before receiving ethylene treatment, changed their color irrespective of the number of ethylene applications. Among the fruits exposed to only one application, $82 \%$ reached the 3 and 4 color index, whereas among those that received two applications, $68 \%$ reached a color index of 5 after 5 days. Fifty-nine percent of the control samples that were held in the controlled temperature and humidity chamber at $45^{\circ} \mathrm{F}$ and 75 to $85 \%$ 
TABLE 2.-Weight loss duving storage of ethylene treated pineapplet

\begin{tabular}{ccccc}
\hline & \multicolumn{4}{c}{ Storage Time } \\
\cline { 2 - 5 } $\begin{array}{c}\text { Ethylene } \\
(0.1 \%)\end{array}$ & 0 & $5\left(45^{\circ} \mathrm{F}\right)$ & $3\left(68^{\circ} \mathrm{F}\right)$ & $\begin{array}{c}\text { Total } \\
\text { wt loss }(\%)\end{array}$ \\
\hline 1 shot & $1835.6^{2}$ & 1803.2 & 1742.9 & 5.05 \\
\hline 2 shots & 1748.7 & 1709.8 & 1643.7 & 5.45 \\
\hline
\end{tabular}

'Stored for 5 days at $45^{\circ} \mathrm{F}$ after treatments followed by an additional 3 days at $68^{\circ} \mathrm{F}$.

${ }^{2}$ Values are expressed in grams. They represent the average of 20 samples. The differences in weight among treatments are not significant $(\alpha=0.05)$.

relative humidity for 5 days without any ethylene application remained green.

When stored for three additional days under simulated supermarket conditions $\left(68^{\circ} \mathrm{F}\right)$, most of the fruits reached a color index of 5 irrespective of the ethylene applications. Under these same conditions, none of the control fruits reached the color index of 5 after 5 days, whereas $80 \%$ reached the color index of 3 after 8 days of storage.

Table 2 presents the weight loss of ethylene-treated pineapples during storage. The data shows that no significant difference in weights was observed between treatments. A $5 \%$ weight loss was observed after the fruits were left for 3 additional days at market conditions $\left(68^{\circ} \mathrm{F}\right)$.

Table 3 presents results of the chemical composition before and after degreening and storage at different temperatures. The storage time, temperatures, and ethylene treatment did not appreciably affect the $\mathrm{Brix}, \mathrm{pH}$ and percentage of total solids values. The results suggest that degreening the fruits did not affect their chemical characteristics.

Table 4 shows the results of taste panel evaluation of treated and untreated samples. The data indicate that fruits exposed in three different field heat removal temperatures and stored for 5 to 8 days at different temperatures did not exhibit significant differences $(\alpha 0.05)$ in their sensory attributes. The values reported for appearance, flavor, texture

TABLE 3.-Chemical composition' of pineapple after degreening and storage at different temperatures

\begin{tabular}{lllcccc}
\hline $\begin{array}{c}\text { Temperature } \\
\left({ }^{\circ} \mathrm{F}\right)\end{array}$ & Days & ${ }^{\circ} \mathrm{Bx}$ & $\mathrm{pH}$ & Acidity & $\begin{array}{c}\text { \% Total } \\
\text { Solids }\end{array}$ & ${ }^{\circ}$ Brix/Acid \\
\hline $79^{2}$ & 0 & 15.20 & 3.59 & 0.68 & 15.80 & 22.35 \\
45 (control) & 5 & 15.20 & 3.29 & 0.82 & 15.65 & 18.54 \\
45 & 5 & 15.38 & 3.30 & 0.86 & 15.80 & 17.88 \\
68 (control) & 8 & 1530 & 3.23 & 0.84 & 15.94 & 18.21 \\
68 & 8 & 15.32 & 3.31 & 0.90 & 15.80 & 17.02 \\
\hline
\end{tabular}

'Values are the computed average of 12 samples.

${ }^{2}$ Initial fruit temperature after harvest. 
TABLE 4.-Sensory evaluation of Red Spanish pineapple after field heat removal and ethylene treatment

\begin{tabular}{lccccc}
\hline & & & \multicolumn{2}{c}{ Mean Values' } & \\
\cline { 4 - 5 } Temperature & Days & Appearance & Flavor & Texture & Overall quality \\
\hline $79^{2}$ & 0 & 4.25 & 4.58 & 4.83 & 4.58 \\
$78-82$ & 5 & 4.67 & 4.25 & 4.67 & 4.25 \\
45 & 5 & 4.67 & 4.48 & 4.25 & 4.33 \\
68 & 5 & 4.83 & 4.83 & 5.08 & 4.83 \\
45 (no ethylene) & 5 & 4.58 & 4.58 & 4.33 & 4.33 \\
$78-82$ & 8 & 5.11 & 4.67 & 4.77 & 4.67 \\
45 & 8 & 5.00 & 4.67 & 4.89 & 4.55 \\
68 & 8 & 4.78 & 4.33 & 4.44 & 4.77 \\
\hline
\end{tabular}

16- fruit scale: 6 = like very much; 1 - do not like. Values within each attribute (appearance, flavor, etc.) are not significantly different $(\alpha=0.05)$.

"Initial fruit temperature after harvest.

and overall quality were all considered acceptable (according to the taste panel, the overall quality of the fruits was considered acceptable). No significant differences were observed between untreated fruits and those treated with ethylene and kept at $45^{\circ} \mathrm{F}$ or $68^{\circ} \mathrm{F}$.

This study indicates that mature green Red Spanish pineapple can be treated with ethylene for $24 \mathrm{~h}$ immediately before shipping to assure removal of the green pigment, thus making them more attractive to potential consumers.

\section{LITERATURE CITED}

1. Anonymous, 1988. Situación y Perspectiva de la Empresa de Piña en Puerto Rico, Dep. Econ. Agric. Esta. Exp. Agric., Rlo Piedras, P.R.

2. Baum, A., E. Godschmidt and S. Benyehoshua, 1976. Involvement of Endogenous Ethylene in the Induction of Color Change in Shamouti oranges. Plant Physiol. 57, 836-38.

3. Cancel, H. L., 1974. Harvesting and Storage conditions for Pineapple of the Red Spanish Variety. J. Agric. Univ. P.R. 58 (2): 162.

4. Kenneth, G. R. and R. Paul, 1988. Incidence and Severity of Chilling Induced Internal Browning of Waxed "Smooth Cayenne" Pineapple. J. Am. Soc. Hort. Sci. 107 (3): 453.57.

5. Mariott, J. and F. J. Procton, 1978. Transportation and Conservation of Tropical Fruits. Outlook on Agric., 9: 233-239.

6. Pantastico, E. B., 1975. Postharvest Physiology, Handling, and Utilization of Tropical and Subtropical Fruits and Vegetables. AVI. Publ. Co., Westport, Ct.

7. Rayall, A. L. and W. T. Pentzer, 1982. Handling, Transportation and Storage of Fruits and Vegetables. Vol. 2, 2ed. AVI Publ. Co., Westport, Ct.

8. Sommer, N. F., 1985. Postharvest Handling Systems: Tropical Fruits. In: Kade, A. A., R. F. Kasmire, F. G. Mitchell, M. S. Reid, N. F. Sommer, and J. F. Thompson. Postharvest Technology of Horticulture Crops, Univ. Calif., Div. of Agric. \& Nat. Resources, Special Publ. 3311. 